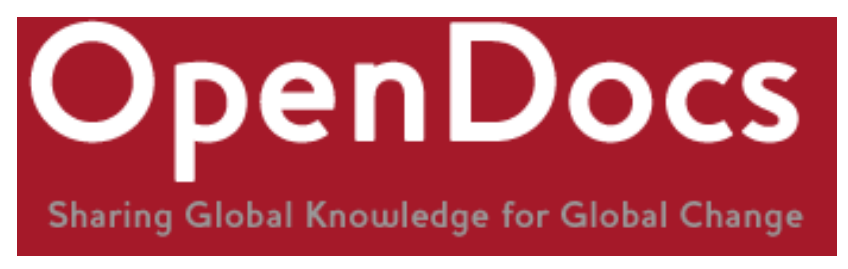

Title: Why agronomy in the developing world has become contentious

Citation: Sumberg, J., J. Thompson and P. Woodhouse. (2013). Why agronomy in the developing world has become contentious. Agriculture and Human Values 30(1): 71-83

Official URL: http://link.springer.com/article/10.1007/s10460-012-9376-8

More details/abstract: In this paper we argue that over the last 40 years the context of agronomic research in the developing world has changed significantly. Three main changes are identified: the neoliberal turn in economic and social policy and the rise to prominence of the participation and environmental agendas. These changes have opened up new spaces for contestation around the goals, priorities, methods, results and recommendations of agronomic research. We suggest that this dynamic of contestation is having important effects on how agronomic research is planned, managed, implemented, evaluated and used, and is therefore worthy of detailed study. This is particularly so at a time when food security, rising food prices and the potential impacts of climate change on agriculture are in the policy spotlight. We outline a research agenda that should help illuminate the drivers, dynamics and impacts of this new 'political agronomy'.

Keywords: conservation agriculture, SRI, agricultural research, political ecology

Version: Submitted version

Terms of use: This work has been licensed by the copyright holder for distribution in electronic format via any medium for the lifetime of the OpenDocs repository for the purpose of free access without charge. The final publication is available at http://link.springer.com/article/10.1007/s10460-012-9376-8

This is a download from OpenDocs at the Institute of Development Studies

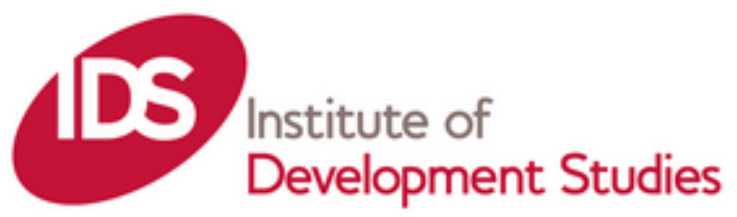


Why agronomy in the developing world has become contentious

James Sumberg ${ }^{1}$, John Thompson ${ }^{1}$, Philip Woodhouse ${ }^{2}$

${ }^{1}$ Institute of Development Studies, University of Sussex, Brighton, BN1 9RE

${ }^{2}$ School of Environment and Development, University of Manchester, UK

Pre-print version. Eventually published as: Sumberg, J., J. Thompson and P. Woodhouse. (2013). Why agronomy in the developing world has become more contentious. Agriculture and Human Values 30(1): 71-83 


\section{Why agronomy in the developing world has become contentious}

Abstract In this paper we argue that over the last 40 years the context of agronomic research in the developing world has changed significantly. Three main changes are identified: the neoliberal turn in economic and social policy and the rise to prominence of the participation and environmental agendas. These changes have opened up new spaces for contestation around the goals, priorities, methods, results and recommendations of agronomic research. We suggest that this dynamic of contestation is having important effects on how agronomic research is planned, managed, implemented, evaluated and used, and is therefore worthy of detailed study. This is particularly so at a time when food security, rising food prices and the potential impacts of climate change on agriculture are in the policy spotlight. We outline a research agenda that should help illuminate the drivers, dynamics and impacts of this new 'political agronomy'.

Keywords conservation agriculture, SRI, agricultural research, political ecology

\section{Introduction}

Over the last decade agronomists and others interested in agriculture in the developing world have become embroiled in debates about the origins, technical performance and environmental and social merits of the System of Rice Intensification (SRI) (Dobermann, 2004; Latif et al., 2005; McDonald et al., 2006, 
2008; Moser and Barrett, 2003; Satyanarayana et al., 2007; Senthilkumar et al., 2008; Sheehy et al., 2004; Sinha and Talati, 2007; Stoop et al., 2009; Stoop and Kassam, 2005; Stoop et al., 2002; Uphoff et al., 2008) and Conservation Agriculture (CA) (Chivenge et al., 2007; Giller et al., 2009; Govaerts et al., 2009; Gowing and Palmer, 2008; Hobbs, 2007; Hobbs et al., 2008; Kassam et al., 2009). These debates have been high profile, sustained and at times acrimonious and emotive. They have taken place in the academic journals that help define and legitimise modern agronomy, as well as through the internet and other channels. While the debates around SRI and CA have been particularly hard fought, and we highlight them in this paper for exactly that reason, there are a number of other examples of contestation within contemporary development agronomy relating to integrated pest management (IPM) (Orr and Ritchie, 2004; Van Huis and Meerman, 1997), bio-fortification (Dawe et al., 2002; Pfeiffer and McClafferty, 2007) and agro-ecology (Altieri, 2002; Woodhouse, 2010).

Drawing from Sumberg et al. (2012b), the argument we develop here is that this contestation reflects three important changes in the context within which agronomic research - and agricultural research more broadly - takes place. Specifically, since the mid-1970s the context of agronomic research has changed through (i) the promotion of a 'neoliberal project'; (ii) the emergence of the environmental movement; and (iii) the rise of the participation agenda in agricultural research. We suggest that these changes undermined the long-standing unity of purpose between government policy and agronomic objectives which dominated the politics of agricultural science for much of the last century. This radical transformation in the context of agronomic research has opened up of new spaces for contestation of its goals, priorities, methods, results and recommendations; with profound consequences for both agronomic research and researchers, and the policies, institutions, interests and individuals they are meant to serve. 
We refer to the analysis of these changes and their impacts - including increased debate and contestation - as 'political agronomy'. Analysis along these lines is particularly relevant at this point in time because the new focus on agriculture (e.g. de Janvry and Sadoulet, 2010; The World Bank, 2007) and 'agricultural research for development' (von Kaufmann, 2007), combined with the continuing turmoil in world food markets and uncertainty around the future effects of climate change on food production and availability (Foresight, 2011), all draw attention to the critical role of agronomic research. A better understanding of the politics around everyday agronomy and agronomic research will be particularly valuable if these challenges are to be addressed successfully and sustainably.

The remainder of this paper is divided into two parts. In the next section we further develop the elements of the argument set out above. Following this we trace some of the main contours of a political agronomy analysis and sketch the beginnings of a research agenda. Because of renewed interest in the agricultural sector and the continent-wide effort to promote an 'African Green Revolution', our analysis is focused largely but not exclusively on sub-Saharan Africa.

Before proceeding three caveats are required. First, as will become evident in the next section, our identification of a disjuncture since the mid-1970s is not to suggest that agronomic research existed outside the political arena prior to the rise of neo-liberal, environmental and participation agendas. Indeed, there is a significant body of scholarship focused on the political economy of agricultural research both before and after the implementation of the neoliberal project (Busch, 1981; Buttel and Busch, 1988; Hadwiger, 1982). Rather, we argue that the 1970s saw the end of a half-century dominated by state-led programmes of agricultural modernization that had largely defined the economic and institutional (political) relationships between science and agricultural production in industrialized and developing economies alike. 
Second, this paper is not driven by a desire to denigrate or dismiss agronomic research or agronomists, whether they are working in the public sector, agroindustry, the international centres of the Consultative Group on International Agricultural Research (CGIAR) or anywhere else. Rather, our objective is to better understand their responses to the changing opportunities, challenges and incentives they face. This kind of analysis should help increase scientific understanding by helping to illuminate the blind spots of the scientific enterprise.

Finally, our focus on the politics of formal agronomic research should not be read either as signalling acceptance of a simple linear model of agricultural technology development or as denial of the importance of farmer knowledge, experimentation and agency. Indeed our analysis is underpinned by a systems of innovation perspective (Hall et al., 2001) that views formal agronomic research as but one (important) part of a rich, interactive picture in which producers, service providers and others are intimately involved in knowledge generation and innovation processes, and where decisions about technology use are iterative, contingent and socially embedded (Scoones and Thompson 1994, 2009).

\section{The contested agronomy argument}

\subsection{Agronomy and the state}

Agronomy is a core discipline within agricultural science. While there are different traditions within agronomy it is most broadly conceived as a scientific and intellectual endeavour that seeks to understand and affect the biological, ecological, physical, socio-cultural and economic basis of crop production and land management. More narrowly, and particularly within the Anglophone tradition, agronomy is usually understood to be the application of plant and soil science to crop 
production. Agronomic research takes place on experiment stations, in laboratories and on farmers' fields: it is by-and-large an applied and practical undertaking, and agronomists only rarely find themselves in the political or public limelight.

Until the mid-late $20^{\text {th }}$ century most formal agronomic research in both the developed and developing worlds took place within state-funded institutions (universities, ministries and research institutes) (Ruttan, 1982). In this sense agronomic research was very much of the state, supporting the state's economic, political and social policy agendas through the generation of practical knowledge and applied technology. It should not be surprising, therefore that agronomy developed as a normative academic discipline.

Agronomic research as 'state intervention' (Dale, 1981) operated at a variety of levels to support policy objectives including state security, the consolidation of state boundaries, colonial expansion and exploitation, 'cheap food' and agricultural modernisation. From the work of Bonneuil (2000) and others it is clear that the agronomic research which took place on experiment stations throughout colonial Africa, was a critical component of strategic colonial era projects such as the Gezira Scheme, the East Africa Groundnut scheme, the Niger Agricultural Project in Nigeria's Middle Belt and the Office du Niger in what is now Mali. With the objective of producing raw materials to fuel European industrial expansion (e.g. groundnuts), cut historic inter-European dependencies (e.g. cotton) and European dependence on America (e.g. for vegetable oil, Franke and Chasin, 1980), these projects and the agronomic research that supported them served both economic and geo-political purposes.

Agronomists also were associated with the development and promotion of 'mixed farming' as a model for agricultural development in sub-Saharan Africa (SSA). Initially framed as a response to soil erosion and deforestation, mixed farming soon became an overarching framework for the spatial, social and economic re- 
organisation of the African countryside, including an explicit goal of creating and supporting a new class of 'peasant farmers' (Sumberg, 1998; Wolmer and Scoones, 2000). It is true that in accepting some pieces of the mixed farming model while rejecting others, farmers both resisted the state's advances and exercised their agency. Nevertheless, it is impossible to escape the conclusion that agronomists played an important part in the implementation of colonial states' political and social agendas by giving scientific credence to the analysis of the problem (e.g. deforestation, soil erosion, low productivity) and by providing new agricultural technology (cf. Bonneuil, 2000).

In the post-World War II (in Europe and the North America) and post-colonial periods (in Africa and Asia), agronomic research operated within a policy and funding context that set uncontroversial objectives, such as increasing the supply of food to address hunger and a rapidly-growing world population. In addition to humanitarian objectives, investment in research to boost productivity in Asia and Latin America served the West's geopolitical goals: a Green Revolution to counter the threat of communist insurgency (Farmer, 1981).

Our central contention is that because of the historical context within which agronomy developed as a field of academic study and as a problem-solving science - i.e. where national governments unified both funding and research priorities according to public policy objectives - agronomic research experienced a long period during which scope for contention about priorities, objectives, methods or the meaning of success was narrowly circumscribed. As outlined in the next section, however, the period of long-standing unity of purpose between government policy and agronomic objectives has ended.

\subsection{A changing context}


Our argument focuses on three related developments that emerged in part as responses to a critique of state-led development as inefficient, environmentally damaging and undemocratic.

\subsubsection{The neoliberal project}

We use the term neoliberal project to refer to the wave of economic liberalisation and state reform that emerged initially in the USA and the UK in the late 1970s and early 1980s. The economic and social policies of Ronald Reagan and Margaret Thatcher, built around the belief that markets are the most efficient way of allocating resources and hence of achieving the greatest public good, set out the major lines of the neoliberal project. The interest in strengthening the role of markets while shrinking the state came together in what came to be called the 'Washington Consensus' (Williamson, 1993), which was imposed throughout much of the developing world and post-Cold War Europe through structural adjustment programmes of the World Bank and International Monetary Fund (Streeten, 1987). It is important to note that despite the zeal behind the Washington Consensus, the same 'market principles' have yet to be fully integrated into US or EU agricultural policy.

The neoliberal project directly and significantly affected agronomy research and the agricultural sector more broadly via changes to intellectual property rights. Beginning in the 1960s the laws in Europe and the USA governing crop variety protection were strengthened, reflecting a more global evolution of intellectual property regimes (Tansey and Rajotte, 2008). These changes incentivised greater private sector investment in crop breeding. When combined with the revolution in cell biology and bio-engineering, which were themselves stimulated by the new intellectual property regimes, the growing role of the private sector in crop breeding 
set the stage for a root and branch restructuring and consolidation of the agro-inputs industry (Bijman, 2001; Wield et al., 2010).

The effects of the neoliberal project on state-funded agricultural research, particularly in SSA, came in the 1980s when economic crisis forced governments to agree to Structural Adjustment Programmes with the World Bank and International Monetary Fund. In addition to exchange rate and fiscal reforms, these programmes followed the Berg Report's (1981) arguments that state provision and/or subsidization of inputs and services - including research, extension services, irrigation, fertilizers, seeds and credit - caused inefficiencies, distortions and corruption, while putting an unsustainable burden on state finances. Consequently, state agencies providing these were targeted for reform or privatisation and any subsidy elements eliminated or radically reduced. State involvement in agricultural marketing (e.g. through marketing boards) and processing was also targeted (Bates, 1981; Jayne et al., 2002; Sandbrook, 1985).

\subsubsection{The environmental agenda}

The publication of Silent Spring in 1962 (Carson, 1962) was a significant landmark that drew public attention to the ecological damage associated with widespread use of the insecticide DDT. In so doing, Carson set the stage for a broader interrogation of the environmental and health impacts of the chemical intensive, large-scale farming operations that state-funded research had helped develop in the pursuit of modernization and 'cheap food' (Cook, 1989; Smith, 2001). In the developing world, the Sahel droughts of the late 1960s and early 1970s - and the spectre of the desert marching south to the Guinea coast - cast doubt on the ability of these environments to support conventional models of agricultural intensification. By the 1980s concerns were being raised in Asia about the 
environmental and related health consequences of the Green Revolution, including water pollution from fertiliser use, water-logging and soil salinisation, biodiversity loss and human poisoning associated with pesticide use (Loevinsohn, 1987; Pimentel and Pimentel, 1990; Pingali and Rosengrant, 1994).

These concerns, combined with a perception that the Green Revolution had gained limited ground in marginal areas, fuelled interest in a number of alternative approaches including agro-ecology (Conway, 1985) and 'low external-input' farming (Reijntes et al., 1992; Tripp, 2005). While these alternatives were frequently shunned by mainstream agronomists (see Vanloqueren Baret, 2009), the promise of a more environmentally-friendly agriculture made them particularly attractive to some NGOs and development funders (De Jager et al., 2001; Low, 1994; Reij and Waters-Bayer, 2001).

The rapid spread of Green Revolution rice and wheat varieties in Asia, events such as the 1970 epidemic of southern corn leaf blight in the USA (Tatum, 1971), and the signing of the 1993 Convention on Biological Diversity (CBD) drew attention to the risks associated with narrowing the crop genetic resource base (Pistorius 1997). Maintenance of agro-biodiversity, particularly in marginal areas where it was portrayed as a key to local adaptation strategies, soon became an important plank of the environmental agenda, which was reinforced by the signing of the International Treaty on Plant Genetic Resources for Food and Agriculture (ITPGRFA) in 2004 and the recognition of 'Farmers' Rights'.

\subsubsection{The participation agenda}

There are two related aspects of the participation agenda that require attention. The first, rooted in populist calls for a shift in the relations between the state, elites and the poor, was inspired by works such as Paulo Friere's Pedagogy of 
the Oppressed (2007) and framed in terms of social justice, rights and empowerment (Chambers, 1993, 1997; Chambers and Ghildyal, 1985; cf. Cornwall, 2003). The second grew out of the neoliberal project's interest in increasing the efficiency of the state through promotion of administrative decentralisation and the use of market mechanisms to deliver services to the poor (Leal, 2007). Here, people became 'stakeholders' and participation was more about development management than emancipation and justice (Cooke, 2003). The ambiguity arising from the divergent origins of the participation agenda, coupled with the rapid permeation of participatory rhetoric throughout development policy, soon led to probing questions about its emancipatory potential (Cooke and Kothari, 2001; Gow and Vansant, 1983; Weyland, 1996).

For agronomic research, the participation agenda has been highly significant. A view that the Green Revolution had widened the gap between richer and poorer rural people (Pearse, 1980) and had provided few benefits for people in 'low potential' areas, highlighted claims about the irrelevance of research-generated technologies and a rising hostility to anything that smacked of technology transfer or so-called top-down and blueprint approaches to development. This set the stage for a sustained attack on agricultural research and researchers (Richards, 1985), and the norms and values of agronomists' 'normal professionalism', as being those of elites, cut off from rural realities, ill informed and lacking interest in or respect for local people and their indigenous knowledge (Chambers, 1993, 1986, 1997). It is important to note, however, that this view is at odds with studies that demonstrate high returns to investment in agricultural research in the developing world and the growing use of technologies produced by formal research, even among poor farmers in SSA (e.g. Dalton and Guei, 2003; Maredia et al., 2000; Maredia and Raitzer, 2010; Raitzer and Kelley, 2008). 
These critiques and the mixed experience with farming systems research (Biggs, 1995; Collinson, 2000) helped fuel a new interest in 'farmer participatory research' (Okali et al., 1994), 'participatory technology development' (Haverkort et al., 1991), and many other 'farmer first' approaches (Chambers et al., 1989; Scoones and Thompson, 1994, 2009). In practice farmer participatory research laboured under confused objectives (more effective research, or empowerment of the rural poor?) (Okali et al., 1994; Thompson and Scoones, 1994), although there have been sustained efforts to develop more inclusive approaches to crop improvement through 'participatory plant breeding' (Almekinders and Elings, 2001; Sperling et al., 2001).

In Latin America, in line with the neo-liberal project's goal of making agencies of the state more 'client oriented', there was considerable emphasis on the development of mechanisms that would give farmers more control over agricultural research priorities and resources (Ashby et al., 2000). In SSA the participation agenda highlighted women's role in agriculture, the need for researchers to take better account of intra-household dynamics (Moock, 1986), and the need to empower women vis-à-vis agricultural research (Sperling and Berkowitz, 1994). More recently, the participation agenda has been associated with the emergence in Latin America and Asia (and to a lesser extent in SSA) of rural social movements campaigning on issues such as landlessness, corporate control over agricultural technology and 'food sovereignty' (Akram-Lodhi, 2007; McMichael, 2008; Patel, 2009; Teubal, 2009).

\subsection{Impacts on agronomic research}

The changes in context outlined above have had important direct and indirect impacts on agronomic research. The nature and extent of these impacts have varied tremendously - across regions, countries and commodities - depending, for example, on the historical and institutional context, the policy environment and the 
size and coherence (and level of dependency on development assistance) of agricultural research systems.

Structural adjustment programmes set out to 'reform' and 'strengthen' public sector agricultural research by improving focus, efficiency and accountability (to both funders and users such as farmers). In many cases this meant rationalisation of objectives, programmes and research facilities, reduced staffing levels, new incentive regimes and streamlined management structures (Berg, 1981; Byerlee, 1998; Byerlee and Alex, 1998). The effects of these programmes on agricultural research were generally more profound where research systems were smaller and weaker, as is generally the case in sub-Saharan Africa. Many developing countries where agriculture is relatively commercialised have seen increasing private sector investment in agricultural research (Naseem et al., 2010). This has forced the public sector - including the CGIAR - to re-frame its role in terms of the provision of 'public goods' (Anderson, 1998; Gardner and Lesser, 2003; Harwood et al., 2006; Lele and Gerrard, 2003). This evolving context also resulted in new emphasis on the creation of partnerships, alliances and 'learning platforms': the CGIAR Challenge Programmes, for example, clearly reflected these shifting institutional, funding and political landscapes, as does the increasing prominence of the language of 'publicprivate partnerships' in relation to international agricultural research (Spielman et al., 2010). More recently, fifteen large-scale, long-term programmes (CGIAR Research Programmes or CRPs) designed to be of global significance have emerged from the CGIAR restructuring process. The CRPs are distinguished by their scope and ambition (the Global Rice Science Partnership, for example, is designed as a 25year, US\$ 3 billion effort), and they all emphasise partnership and collaboration across very diverse groups of research and development actors.

Taken together these shifts have had important implications not only for what research areas or questions are prioritised by the public sector, but also for the 
choice of methods, research sites and partnership arrangements. Associated changes in funding, and the new emphasis on accountability and impact, favour downstream over upstream and short-term over long-term research, and play themselves out through the thousands of everyday decisions made by those who fund, manage and do agronomic research.

\subsection{New spaces for contestation}

The changes highlighted above have created new spaces in which agronomic research can be and is being contested. On the one hand, the old unity of purpose between agricultural research and state policy has been undermined by the thrust of neoliberal policies combined with public budget deficits, the arrival of new research actors and funders, calls for participation and client orientation, and the mass availability of information and communication technologies. On the other hand, those opposing increasing corporate control of the global food system have sought to open science and technology policy processes to greater scrutiny and popular participation.

Three distinct spaces for contestation can be identified. The first is associated largely with peer-reviewed journals, the traditional channel for the communication of agronomic research findings. In recent years, mainstream journals such as Field Crops Research, Agricultural Systems, Experimental Agriculture, Soil \& Tillage Research, Journal of Agricultural Science, Agricultural Water Management and Critical Reviews of Plant Sciences have published vigorous and extended exchanges around for example the System of Rice Intensification (McDonald et al., 2006;

Sheehy et al., 2004; Stoop et al., 2002; Uphoff et al., 2008) and Conservation Agriculture (Giller et al., 2011; Giller et al., 2009; Jenrich, 2011; Marongwe et al., 2011; Nkala et al., 2011; Owenya et al., 2011; Silici et al., 2011). These exchanges 
articulate around contested 'facts' such as the theoretical yield ceiling for rice, the yield levels achieved by farmers using SRI, and the extent of the spread of SRI in Asia. There has also been contestation around appropriate methods for comparing the performance of complex technologies like SRI. For Conservation Agriculture, contestation has centred on its suitability for smallholders in dryland areas of southern Africa. Other examples of contestation include the performance, benefits and risks associated with the use of genetically engineered crops by smallholder farmers.

It is not that debate - indeed contestation - is entirely new to journals such as these. Indeed there have been long-running exchanges about the relative merits of alternative experimental designs and sampling strategies, and the proper interpretation of statistical analyses. [Here it is important to remember that most of the contestation about the Green Revolution in Asia was amongst economists and social scientists and appeared in journals not normally associated with agronomists or agronomic research.] Rather we argue that the nature of the contestation has changed, reflecting in part epistemological divisions between, for example, the 'scientific' approach that provides the main underpinning of agronomic research, and constructivist approaches that privilege the social basis - and thus the politics - of knowledge creation and use (Fairhead and Leach, 1996).

A second set of spaces for contestation arose when agricultural research organisations sought greater engagement with their clients and opened themselves to greater public scrutiny. In many countries national and sub-national committees were established to help set priorities, monitor progress and in some cases make funding decisions. At the international level, in 1995 the CGIAR established the CGIAR-NGO Partnership Committee to address concerns on the part of some NGOs that the international research centres were not being responsive to the needs of poor farmers. The Committee experienced deep divisions over its role and focus, as 
well as research policy and priorities, and by the time of the CGIAR's Annual General Meeting in 2003 these divisions were being described as 'irreconcilable' (CGIAR, 2003, 2006). During the recent CGIAR re-organisation exercise there was renewed pressure for broader stakeholder engagement although the preferred mechanism changed to the Global Forum on Agricultural Research (GFAR) and the 2010 Global Conference on Agricultural Research for Development (GCARD) (CGIAR, 2006; GFAR, 2011). The International Assessment of Agricultural Knowledge, Science and Technology for Development (IAASTD) process (Mclntyre et al., 2009) is another important example. From 2005 through 2007, the IAASTD evaluated the relevance, quality and effectiveness of agricultural knowledge, science, and technology (AKST), as well as associated policies and institutional arrangements. Drawing on experiences from Intergovernmental Panel on Climate Change (IPCC) and the Millennium Ecosystem Assessment the IAASTD adopted an expert-led scenario approach to explore uncertain scientific, technological and policy futures. Input was from over 900 stakeholders representing scientific, public, private and civil society organisations around the world. In theory, such an inclusive approach can confer political legitimacy and credibility on a complex assessment process; but in practice the process was highly contentious because of different ideologies, world views, understandings of poverty and its causes, views of the agricultural economy and the role of the private sector with it, and divergent appreciations of agronomic knowledge (Feldman and Biggs, 2012; Scoones, 2009)

The development of the internet and information and communication technologies (ICTs) has opened a third set of spaces that allow debate about agricultural research in the developing world to move outside established academic and policy arenas (see Buttel, 2005). This space has been particularly important for NGOs and other civil society organisations. The World Wide Web is now replete with sites advocating or criticising specific technologies such as Bt cotton, Conservation 
Agriculture, Drought Tolerant Maize for Africa, Golden Rice and the System of Rice Intensification. Some of these sites draw from the journal-based debates cited above; others collate information and experiences from a broader range of sources in order to serve specific communities of interest; and still others are essentially public relations or marketing efforts by research organisations, funders, development organisations and private firms promoting their scientific achievements and innovations. The lack of peer review or other quality control mechanisms means that poor quality evidence and unsupported conclusions can lead to the propagation of claims about agronomic research and technologies that are partial, ill-informed or simply wrong (Orr et al., 2008).

The opening up of these new spaces of contestation has made agricultural policy processes more noisy and messy - and more overtly political - at a moment when food systems and the policy-makers who seek to guide and regulate their development confront many new challenges such as rising demand for food, climate change and potentially revolutionary biological technologies (e.g. Scoones, 2009). While this might be seen as 'business as usual' in other policy areas, from an agricultural research perspective it represents a move into new and unfamiliar territory.

Some observers argue that an 'opening up' to new methods and practices that enhance flexibility, diversity, adaptation and reflexivity is a logical response to the incomplete knowledge available about the nature and dynamics of these challenges (Leach et al., 2010). Yet, in the spaces we identified above, rather than opening-up, there is a tendency - supported by professional, institutional, business and political pressures - for powerful actors and institutions to attempt to 'close down' or limit discussion in favour of particular research agendas and development pathways such as Conservation Agriculture (Andersson and Giller, 2012), genetically engineered crops (Vanloqueren and Baret, 2009) and micro-nutrient biofortification of 
crops (Brooks and Johnson-Beebout, 2012). The result is the continued promotion of universal approaches to both policy and practice which obscure alternative framings and pathways, and downplay contextual factors.

\section{The contours of political agronomy analysis}

We see political agronomy analysis focusing principally on the evolving practices of everyday agronomic research and the factors affecting this evolution. This should include specific focus on the role of framing and narrative in contextualising, justifying and prioritising some research topics, areas and approach over others. Closely related to this is concern with the processes and politics of research agenda setting. The new dynamics of partnership and collaboration should be a major focus of political agronomy, and this will help bring into focus the important role of epistemic communities within agronomy. Finally, political agronomy analysis must include a focus on how the legitimacy of research is both established and contested, and how particular narratives and policy framings can be supported or undermined by the way that research results are presented and interpreted. We explore these points in more detail below highlighting some of the research questions that should underpin such an analysis.

\subsection{Framing and narratives}

The importance and politics of problem framing is now widely recognised in the social and political sciences (Bardwell, 1991). Here, framing refers to 'the process of selecting, emphasizing, and organizing aspects of complex issues, according to overriding evaluative or analytical criterion' (Daviter, 2007, p.654). The basic observation that underpins the interest in framing is that in some situations small 
changes 'in the presentation of an issue or an event produce (sometimes large) changes of opinion' (Chong and Druckman, 2007, p.104): this is referred to as 'the framing effect'. Framing determines to a significant degree how much attention the problem receives and the approach taken to address it, and thus prefigures the eventual solution(s). By way of example we can cite two alternative framings of genetically engineered crops: as 'technology for the poor' (Glover, 2010; Jansen and Gupta, 2009) or as 'Frankenfoods'. Framing sets the stage for narratives or storylines about a given problem: how it has arisen, why it matters and what should be done about it (Keeley and Scoones, 2003; Roe, 1991).

The pertinence of framing to a political agronomy analysis is illustrated by the implications of re-framing the challenge for cropping systems research from, for example, yield maximisation to resilience. This shift would immediately highlight different research problems, strategies, experimental methods and success indicators (Piepho, 1998; Van Bueren et al., 2002). Another example is soil organic matter management, which has traditionally been framed in terms of soil condition, fertility and crop response. More recently however, in the light of both new insights from soil science and the development of carbon markets, soil organic matter management has been re-framed in terms of 'carbon sequestration' (Perez, et al 2007; Lal 2009), which foregrounds new questions relating to monitoring and markets that were previously of little if any relevance. The example of the re-framing of genetically engineered crops as 'technology for the poor' could shift research agendas toward some areas (e.g. performance under less than optimal conditions; quantification of benefits to poor farmers) and away from other, potentially more sensitive questions such as environmental impacts and increasing corporate control of agricultural input markets.

From a political agronomy perspective, the questions of interest relate to the drivers of processes of framing and re-framing; the actors and relationships involved; 
and the impacts of different framings and narratives on the conception, practice and presentation of agronomic research. For example, Brooks and Johnson-Beebout (2012) show how the framing and re-framing of biofortification of rice within the CGIAR had significant consequences for the research approach, methods and collaborative networks. Similarly, Woodhouse (2012) argues that the impasse in the development of formal irrigation in SSA is due in part to the fact that agronomists have left agricultural water management to either engineers (who frame the challenge in terms of modernization of infrastructure), or to environmentalists (who frame it in terms of resource conservation), but neither of these professional groups have engaged with the current social dynamics of African agriculture.

\subsection{Agenda setting}

Closely related to framing is the question of how agronomic research priorities are determined. While a large literature assumes that prioritisation is (or should be) a rational, technical process (Raitzer and Norton, 2009), an alternative view sees it as a process in which power and politics are of utmost importance. This perspective is useful in analysing why some challenging ideas and innovations are successfully integrated into the agronomic research agenda while others are not. For example, Vanloqueren and Baret (2009) ask, 'Why were GM crops brought quickly within mainstream agricultural research while, in contrast, there has been relatively little funding for research on agroecology?'. This is a political agronomy question par excellence. McGuire (2008) uses notions of path dependency and 'technology lockin' to explain the persistent focus (since 1977) on $F_{1}$ hybrids within the Ethiopian lowland sorghum breeding programme, despite the fact that to date no hybrid varieties have been released. Among many other examples from sub-Saharan Africa 
are the decades of research on fodder legumes and mixed farming despite only limited or partial use by farmers (Sumberg, 2002, 1998; Wolmer and Scoones, 2000).

These examples raise a series of fundamental questions about the direction of agricultural research and who benefits from investments in it. What evidence is used to justify the objectives set for particular agronomic research projects or programmes? To what extent are these objectives (or should they be) rooted in analysis of farmers' practice and priorities? Through what processes are decisions made? How is influence and power brought to bear on these processes; and who gains and who loses as a result? Political agronomy research along these lines would directly address the interactions between local, national and regional actors on the one hand and international agencies, bi-lateral and multi-lateral funders on the other. How do these dynamics affect decision making? For example, Fairhead et al (2012) compare the interest in carbon-enriched, 'anthropogenic dark earth' soils and the use of biochar (charcoal) as a soil amendment in SSA and Brazil to highlight historical and regional differences and disjunctures in agronomic knowledge and the setting of research agendas (e.g. in relation to nutrient or carbon management). This resonates with Andersson and Giller's (2012) analysis of disjunctures and epistemic communities around current efforts to promote Conservation Agriculture among smallholders in southern Africa.

\subsection{Partnership}

There is a strong assertion by funders of agricultural research in the developing world that partnership and collaboration are nearly always desirable. This is couched in terms such as learning, multi-disciplinarity, institution strengthening, capacity building, coalition building and comparative advantage. As such, this assertion both supports and is in turn strengthened by donor investments in training, 
research networks and innovation platforms (Greenland et al., 1987; Plucknett and Smith, 1984). Indeed it is common for funders to insist that agricultural research programmes and projects be designed and implemented collaboratively. Interaction, collaboration, and partnership also are central to systems of innovation theory which has increasingly permeated agricultural research over the last decade (Hall et al., 2001; Sumberg, 2005).

Collaborative research in agronomy takes many forms and ranges in scale and complexity, from individuals in the same department of a single institute collaborating on a project, to complex multi-institutional arrangements such as the CGIAR Challenge Programmes (Spielman et al., 2010) and the new CGIAR Research Programmes. Partners may bring ideas and skills, access to financial resources, or local knowledge, language skills and legitimacy that facilitate access to field sites and target populations. The eventual division of labour and resources should allow each partner to go some way in achieving its mandate. However, the actual workings of these large-scale partnerships and networks in agricultural research have as yet received scant critical attention (de Lattre-Gasquet and Merlet, 1996; Goldberger, 2008; Plucknett and Smith, 1984; cf. Shrum and Campion, 2000). A political agronomy analysis would explore the motivations and incentives that drive and sustain research partnerships. Whose agendas do these arrangements serve? Do they play a role in establishing and legitimizing certain normative framings, and hence delegitimizing others? Who benefits from partnership and how? Can collaboration and partnership be empowering, transformative experiences; if so, in what situations and for whom? To what degree are collaborative arrangements delivering innovation that meets the needs of poor producers? For example, Maat and Glover (2012) use the example of SRI to reflect on the 'partnership' that is arguably at the centre of all agricultural development - that between agronomic research and extension - and argue that different approaches to 
field activities ('experiments' vs. 'demonstrations') result in radically different configurations of the relationship between science and farming practice. Brooks and Johnson-Beebout (2012) analyse the different and changing models of partnership as IRRI's initial work on rice biofortification evolved into the CGIAR HarvestPlus Challenge Programme.

\subsection{Validation}

In earlier sections of this paper we argued that changes in the context within which agronomic research takes place have made it a more open and contested arena. As a result, some foundational assumptions of the discipline concerning its objectives, methods, practices and meanings are being transformed. At issue here is how the knowledge that is generated through agronomic research is produced, validated and communicated. The attacks on the normal professionalism of agricultural research referred to earlier, and the subsequent interest in new, more participatory modes of inquiry posed major challenges to the agronomic research establishment. Unable to articulate a coherent response that identified the potential and limitations of different kinds of participation in different research situations, many researchers, and particularly those who were not in a strong institution or funding position, were swept along by the participation imperative (Sumberg et al., 2003). This could be interpreted as agronomists escaping from a normal science that was no longer 'fit for purpose'. However, a political agronomy perspective demands critical assessment of the dynamics of any such 'liberation', and of whether the use of alternative methods and approaches was linked to clearly articulated research goals, and in turn, whether they enabled progress towards those goals.

Increasing pressure to demonstrate impact has fostered new and innovative politics around impact claims, exemplified by recent efforts to identify, document and 
disseminate 'success stories' about agriculture and agricultural development in Africa (e.g. Spielman and Pandya-Lorch, 2009). Critical analysis includes that by Orr (2003) and Orr and Ritchie (2004) on the success story that has been constructed around IPM in Malawi, and by Orr et al. (2008) on the institutional dynamics behind success claims for NERICA rice. In these cases and others, scientists' claims about the characteristics and potential of the technologies were amplified by the organisations they worked for and funders who supported them, via their use of the World Wide Web and other media. In some cases this amplification led to increased public profile, international accolades and, crucially, continued funding. The importance of claiming impact and celebrating success is only likely to increase in a time of resource scarcity (Sumberg et al., 2012a).

A political agronomy analysis would explore how the changing context is affecting views of the relative value of different research and analytical methods, data sources and dissemination channels. Analysis of the making and use of claims about the impact of agronomic research, and associated institutional and financial dynamics, should offer rich insights into the new world of contested agronomy.

\section{Conclusion}

In this paper we identified three developments since the mid-1970s - the neoliberal project and the rise of the environmental and participation agendas - that have opened new spaces for contestation within and around agronomic research in the developing world. This contestation concerns the goals, priorities, methods, results and recommendations of agronomic research. We argued that analysis of the impact of these changes on agronomic research is of particular importance in the light of climate change, the recent food crises and the renewed interest in the links between agriculture and poverty alleviation. It is also timely, given the increasing 
pressure being applied to agricultural research at all levels to demonstrate impact, success and 'value for money'.

We have outlined what we believe should be the main thrusts of political agronomy analysis and some of the issues and questions that such an analysis could most beneficially address. Specifically, focusing on the practice of everyday agronomic research, we suggested that larger political economy questions may be illuminated by analysis of contestation around framing and narratives, agenda setting, partnership and the validation of the results of agronomic research.

We fully expect the dynamics of change and contestation within and around agronomic research in the developing world to manifest themselves differently depending on a host of contextual factors. Thus an important element of political agronomy analysis will be to map these dynamics and relate them to historical, institutional, political, social and economic contexts.

Political agronomy analysis along the lines we outline will help provide scholars and others with new knowledge and insights into the direction and dynamics of change in agricultural systems, and the roles played by agricultural research in supporting, guiding or constraining change. By highlighting the changing nature of contestation in and around agronomic research, political agronomy analysis addresses the need for fine grained, context specific understandings of the increasingly public struggles for the future of the agrifood in the developing world. Agronomy and agricultural research more generally will remain at the heart of these struggles. At a more fundamental level, recognition of the politically-contested nature of agronomic research agendas suggests a need for research programmes and individual researchers to make more explicit the political and economic assumptions (for example, which social groups are to benefit, how, and why?) that underlie their research goals and methodologies, and to consider more critically what evidence 
supports or undermines those assumptions in the particular social contexts that are the target of the research.

Our contention is that the levels and types of contestation recently associated with, for example, SRI and Conservation Agriculture will have a direct impact on the contribution that agronomic research can make to more sustainable agriculture and livelihood systems in specific contexts. Those who commission, manage or do agricultural research - and those who depend on its technologies, products and outputs, either directly or to further particular policy goals - ignore these dynamics at their peril. Political agronomy analysis of the type outlined here has an important contribution to make in this regard.

\section{References}

Akram-Lodhi, A. H. 2007. Land reform, rural social relations and the peasantry. Journal of Agrarian Change 7: 554-562.

Almekinders, C. J. M. and A. Elings 2001. Collaboration of farmers and breeders: Participatory crop improvement in perspective. Euphytica 122: 425-438.

Altieri, M. A. 2002. Agroecology: the science of natural resource management for poor farmers in marginal environments. Agriculture, Ecosystems \& Environment 93: $1-24$.

Anderson, J. R. 1998. Selected policy issues in international agricultural research:

On striving for international public goods in an era of donor fatigue. World Development 26: 1149-1162.

Andersson, J. and K. E. Giller 2012. On heretics and God's blanket salesmen: contested claims for Conservation Agriculture and the politics of its promotion in African smallholder farming. In Contested Agronomy: Agricultural Research in a Changing World, eds. James Sumberg and John Thompson. London: Routledge. 
Ashby, J. A., A. R. Braun, T. Gracia, M. P. Guerrero, L. A. Hernandez, C. A. Quiros and J. A. Roa 2000. Investing in Farmers as Researchers: Experiences with Local Agricultural Research Committees in Latin America. Cali: CIAT.

Bardwell, L. V. 1991. Problem-framing: a perspective on environmental problemsolving. Environmental Management 15: 603-612.

Bates, R. H. 1981. Markets and States in Tropical Africa: The Political Basis of Agricultural Policies. Berkeley: University of California Press.

Berg, E. 1981. Accelerated Development in Sub-Saharan Africa: An Agenda for Action. Washington, DC: World Bank.

Biggs, S. D. 1995. Farming systems research and rural poverty: relationships between context and content. Agricultural Systems 47: 161-174.

Bijman, J. 2001. Restructuring the life science companies. Biotechnology and Development Monitor 44-45: 26-30.

Bonneuil, C. 2000. Development as experiment: science and state building in late colonial and postcolonial Africa, 1930-1970. Osiris 15: 258-281.

Brooks, S. and S. E. Johnson-Beebout 2012. Contestation as continuity?

Biofortification research and the CGIAR. In Contested Agronomy: Agricultural Research in a Changing World, eds. James Sumberg and John Thompson. London: Routledge.

Busch, L. 1981. Science and Agricultural Development. In Science and Agricultural Development. Totowa, New Jersey: Allanheld, Osmun \& Co.

Buttel, F. H. 2005. Ever since Hightower: The politics of agricultural research activism in the molecular age. Agriculture and Human Values 22: 275-283.

Buttel, F. H. and L. Busch 1988. The public agricultural research system at the crossroads. Agricultural History 62: 303-324.

Byerlee, D. 1998. The search for a new paradigm for the development of national agricultural research systems. World Development 26: 1049-1055. 
Byerlee, D. and G. E. Alex 1998. Strengthening National Agricultural Research Systems: Policy Issues and Good Practice. Washington, D.C.: The World Bank.

Carson, R. 1962. Silent Spring. Boston: Houghton Mifflin.

CGIAR 2003. Consultative Group on International Agricultural Research Annual General Meeting and Stakeholder Meeting, October 29-30 (2003, Nairobi, Kenya: Summary Record of Proceedings Washington, DC: Consultative Group on International Agricultural Research.

CGIAR 2006. A Strategic Framework for Engagement Between the CGIAR and Civil Society Organisations (CSOs) - The CGIAR Perspective. Washington, DC:

Consultative Group on International Agricultural Research Secretariat.

Chambers, R. 1993. Challenging the Professions: Frontiers for Rural Development. London: IT Publications.

Chambers, R. 1986. Normal Professionalism, New Paradigms and Development. Brighton: IDS.

Chambers, R. 1997. Whose Reality Counts: Putting the Last First. London: Intermediate Technology Publications.

Chambers, R. and B. P. Ghildyal 1985. Agricultural-Research for Resource-Poor Farmers: the Farmer-First-and-Last Model. Agricultural Administration 20: 1-30. Chambers, R., A. Pacey and L. A. Thrupp (eds) 1989. Farmer First: Farmer Innovation and Agricultural Research. London: IT Publications.

Chivenge, P. P., H. K. Murwira, K. E. Giller, P. Mapfumo and J. Six 2007. Long-term impact of reduced tillage and residue management on soil carbon stabilization: Implications for conservation agriculture on contrasting soils. Soil \& Tillage Research 94: 328-337.

Chong, D. and J. N. Druckman 2007. Framing theory. Annual Review of Political Science 10: 103-126. 
Collinson, M. P. (ed) 2000. A History of Farming Systems Research. In A History of Farming Systems Research. Wallingford: CABI.

Conway, G. 1985. Agroecosystem analysis. Agricultural Administration 20: 31-55.

Cook, K. A. 1989. The environmental era of U.S. agricultural policy. Journal of Soil and Water Conservation 44: 362-366.

Cooke, B. 2003. A new continuity with colonial administration: participation in development management. Third World Quarterly 24: 47-61

Cooke, B. and U. Kothari 2001. Participation: The New Tyranny? In Participation: The New Tyranny?, eds, B. Cooke and U. Kothari. London: Zed Books.

Cornwall, A. 2003. Whose voices? Whose choices? Reflections on gender and participatory development. World Development 31: 1325-1342.

Dale, C. 1981. Agricultural research as state intervention. In Science and Agricultural Development, ed. L. Busch. Totowa, New Jersey: Allanheld, Osmun \& Co.

Dalton, T. J. and R. G. Guei 2003. Productivity gains from rice genetic enhancements in West Africa: countries and ecologies. World Development 31: 359-374.

Daviter, F. 2007. Policy framing in the European Union. Journal of European Public Policy 14: 654-666.

Dawe, D., R. Robertson and L. Unnevehr 2002. Golden rice: what role could it play in alleviation of vitamin A deficiency? Food Policy 27: 541-560.

De Jager, A., D. Onduru, M. S. van Wijk, J. Vlaming and G. N. Gachini 2001. Assessing sustainability of low-external-input farm management systems with the nutrient monitoring approach: a case study in Kenya. Agricultural Systems 69: 99118.

de Janvry, A. and E. Sadoulet 2010. Agriculture for development in Africa: businessas-usual or new departures? Journal of African Economies 19: ii7-39. 
de Lattre-Gasquet, M. and J. F. Merlet 1996. Agricultural research networks in sub-

Saharan Africa: An analysis of the situation and its consequences. Knowledge,

Technology \& Policy 9: 36-48.

Dobermann, A. 2004. A critical assessment of the system of rice intensification (SRI). Agricultural Systems 79: 261-281.

Fairhead, J. and M. Leach 1996 Misreading the African Landscape: Society and Ecology in a Forest-Savanna Mosaic. London: Routledge

Fairhead, J., M. Leach and K. Amanor 2012. Anthropogenic Dark Earths and Africa: a political agronomy of research disjunctures.In Contested Agronomy: Agricultural Research in a Changing World, eds. James Sumberg and John Thompson. London: Routledge.

Farmer, B. H. 1981. The "Green Revolution" in South Asia. Geography 66: 202-207.

Feldman, Shelley and Stephen Biggs 2012. The politics of international assessments: the IAASTD process, reception and significance. Journal of Agrarian Change 12: 144-169.

Foresight 2011. The Future of Food and Farming: Challenges and Choices for Global Sustainability. Final Project Report. London: The Government Office for Science. Franke, R. and B. Chasin 1980. Seeds of Famine: Ecological Destitution and the Development Dilemma in the West African Sahel. Montclair/New York: Allanheld, Osmun/Universe Books.

Freire, P. 2007. Pedagogy of the Oppressed. New York: Continuum. Gardner, B. and W. Lesser 2003. International agricultural research as a global public good. American Journal of Agricultural Economics 85: 692-697.

GFAR 2011. The GCARD Road Map: Transforming Agricultural Research for Development (AR4D) Systems for Global Impact. Rome: GFAR / FAO. 
Giller, K. E., M. Corbeels, J. Nyamangara, B. Triomphe, F. Affholder, E. Scopel and P. Tittonell 2011. A research agenda to explore the role of conservation agriculture in African smallholder farming systems. Field Crops Research 124: 468-472.

Giller, K. E., E. Witter, M. Corbeels and P. Tittonell 2009. Conservation agriculture and smallholder farming in Africa: The heretics' view. Field Crops Research 114: 2334. doi:

Glover, D. 2010. The corporate shaping of GM crops as a technology for the poor. Journal of Peasant Studies 37: 67-90.

Goldberger, J. R. 2008. Non-governmental organizations, strategic bridge building, and the "scientization" of organic agriculture in Kenya. Agriculture and Human Values 25: 271-289.

Govaerts, B., N. Verhulst, A. Castellanos-Navarrete, K. D. Sayre, J. Dixon and L. Dendooven 2009. Conservation Agriculture and Soil Carbon Sequestration: Between Myth and Farmer Reality. Critical Reviews in Plant Sciences 28: 97-122.

Gow, D. and J. Vansant 1983. Beyond the rhetoric of rural development participation: how can it be done? World Development 11: 427-446.

Gowing, J. W. and M. Palmer 2008. Sustainable agricultural development in subSaharan Africa: the case for a paradigm shift in land husbandry. Soil Use and Management 24: 92-99.

Greenland, D. J., E. T. Craswell and M. Dagg 1987. International networks and their potential contribution to crop and soil management research. Outlook on Agriculture 16: $42-50$.

Hadwiger, D. F. 1982. The Politics of Agricultural Research. Lincoln: University of Nebraska Press.

Hall, A., G. Bockett, S. Taylor, M. V. K. Sivamohan and N. Clark 2001. Why research partnerships really matter: innovation theory, institutional arrangements and 
implications for developing new technology for the poor. World Development 29: 783797.

Harwood, R. R., F. Place, A. H. Kassam and H. M. Gregersen 2006. International public goods through integrated natural resources management research in CGIAR partnerships. Experimental Agriculture 42: 375-397.

Haverkort, B., J. van der Kamp and A. Waters-Bayer 1991. Joining Farmers' Experiments: Experiences in Participatory Technology Development. London: Intermediate Technology Publications.

Hobbs, P. R. 2007. Conservation agriculture: what is it and why is it important for future sustainable food production? Journal of Agricultural Science 145: 127-137. Hobbs, P. R., K. Sayre and R. Gupta 2008. The role of conservation agriculture in sustainable agriculture. Philosophical Transactions of the Royal Society B-Biological Sciences 363: 543-555.

Jansen, Kees and Aarti Gupta 2009. Anticipating the future: `Biotechnology for the poor' as unrealized promise? Futures 41: 436-445.

Jayne, T. S., J. Govereh, A. Mwanaumo, J. K. Nyoro and A. Chapoto 2002. False promise or false premise? The experience of food and input market reform in Eastern and Southern Africa. World Development 30: 1967-1985.

Jenrich, M. 2011. Potential of precision conservation agriculture as a means of increasing productivity and incomes for smallholder farmers. Journal of Soil and Water Conservation 66: 171A-174A.

Kassam, A., T. Friedrich, F. Shaxson and J. Pretty 2009. The spread of Conservation Agriculture: justification, sustainability and uptake. International Journal of Agricultural Sustainability 7: 292-320.

Keeley, J. and I. Scoones 2003. Understanding Environmental Policy Processes: Cases from Africa. London \& Sterling, VA: Earthscan. 
Lal, R. 2009. Sequestering atmospheric carbon dioxide. Critical Reviews in Plant Sciences 28: 90-96

Latif, M. A., M. R. Islam, M. Y. Ali and M. A. Saeque 2005. Validation of the system of rice intensification (SRI) in Bangladesh. Field Crops Research 93: 281-292.

Leach, M., I. Scoones and I. Stirling 2010. Dynamic Sustainabilities: Technology, Environment, Social Justice. London: Earthscan.

Leal, Pablo Alejandro 2007. Participation: the ascendancy of a buzzword in the neoliberal era. Development in Practice 17: 539 - 548.

Lele, U. and C. Gerrard 2003. Global public goods, global programs, and global policies: some initial findings from a World Bank evaluation. American Journal of Agricultural Economics 85: 686-691.

Loevinsohn, M. E. 1987. Insecticide use and increased mortality in rural Central Luzan, Philippines. Lancet 8546: 1359-1362.

Low, A. R. C. 1994. Environmental and economic dilemmas for farm-households in Africa: when low-input sustainable agriculture translates to high-cost unsustainable livelihoods. Environmental Conservation 21: 220-224.

Maat, H. and D. Glover 2012. Alternative configurations of agronomic experimentation. In Contested Agronomy: Agricultural Research in a Changing World, eds. James Sumberg and John Thompson. London: Routledge. Maredia, M. K., D. Byerlee and P. Pee 2000. Impacts of food crop improvement research: evidence from sub-Saharan Africa. Food Policy 25: 531-559.

Maredia, M. K. and D. A. Raitzer 2010. Estimating overall returns to international agricultural research in Africa through benefit-cost analysis: a "best-evidence" approach. Agricultural Economics 41: 81-100.

Marongwe, L. S., K. Kwazira, M. Jenrich, C. Thierfelder, A. Kassam and T. Friedrich 2011. An African success: the case of conservation agriculture in Zimbabwe. International Journal of Agricultural Sustainability 9: 153-161. 
McDonald, A. J., P. R. Hobbs and S. J. Riha 2006. Does the system of rice intensification outperform conventional best management? A synopsis of the empirical record. Field Crops Research 96: 31-36.

McDonald, A. J., P. R. Hobbs and S. J. Riha 2008. Stubborn facts: Still no evidence that the System of Rice Intensification out-yields best management practices (BMPs) beyond Madagascar. Field Crops Research 108: 188-191.

McGuire, Shawn J. 2008. Path-dependency in plant breeding: Challenges facing participatory reforms in the Ethiopian Sorghum Improvement Program. Agricultural Systems 96: 139-149.

Mclntyre, B. D., H. R. Herren, J. Wakhungu and R. T. Watson 2009. Agriculture at a Crossroads: IAASTD Global Report. In Agriculture at a Crossroads: IAASTD Global Report. Washington, D.C.: Island Press.

McMichael, P. 2008. Peasants make their own history, but not just as they please. Journal of Agrarian Change 8: 205-228.

Moock, J. (ed) 1986. Understanding Africa's Rural Households and Farming Systems. In Understanding Africa's Rural Households and Farming Systems. Boulder, CO: Westview Press.

Moser, C. M. and C. B. Barrett 2003. The disappointing adoption dynamics of a yieldincreasing, low external-input technology: the case of SRI in Madagascar. Agricultural Systems 76: 1085-1100.

Naseem, A., D. J. Spielman and S. W. Omamo 2010. Private-sector investment in $R \& D$ : a review of policy options to promote its growth in developing-country agriculture. Agribusiness 26: 143-173.

Nkala, P., N. Mango, M. Corbeels, G. J. Veldwisch and J. Huising 2011. The conundrum of conservation agriculture and livelihoods in Southern Africa. African Journal of Agricultural Research 6: 5520-5528. 
Okali, C., J. Sumberg and J. Farrington 1994. Farmer Participatory Research:

Rhetoric and Reality. London: IT Publications.

Orr, A. 2003. Integrated pest management for resource-poor African farmers: is the Emperor naked? World Development 31: 831-845.

Orr, A. and J. M. Ritchie 2004. Learning from failure: smallholder farming systems and IPM in Malawi. Agricultural Systems 79: 31-54.

Orr, S., J. Sumberg, O. Erenstein and A. Oswald 2008. Funding international agricultural research and the need to be noticed: a case study of NERICA rice. Outlook on Agriculture 37: 159-168.

Owenya, M. Z., W. L. Mariki, J. Kienzle, T. Friedrich and A. Kassam 2011. Conservation agriculture $(C A)$ in Tanzania: the case of the Mwangaza B CA farmer field school (FFS), Rhotia Village, Karatu District, Arusha. International Journal of Agricultural Sustainability 9: 145-152.

Patel, R. 2009. Food sovereignty. Journal of Peasant Studies 36: 663-673.

Pearse, A. 1980. Seeds of Plenty, Seeds of Want: Social and Economic Implications of the Green Revolution. Oxford: Clarendon Press.

Perez, C., Roncoli, C., Neely, C. and J. L. Steiner 2007. Can carbon sequestration markets benefit low-income producers in semi-arid Africa? Potentials and challenges. Agricultural Systems 94: 2-12.

Pfeiffer, Wolfgang $\mathrm{H}$. and Bonnie McClafferty 2007. HarvestPlus: Breeding crops for better nutrition. Crop Science 47: S88-S105.

Piepho, H. P. 1998. Methods for comparing the yield stability of cropping systems - A review. Journal of Agronomy and Crop Science 180: 193-213.

Pimentel, D. and M. Pimentel 1990. Comment: Adverse environmental consequences of the Green Revolution. Population and Development Review 16: 329-332. 
Pingali, P and M Rosengrant 1994. Confronting the Environmental Consequences of the Green Revolution in Asia. EPTD Discussion Paper No. 2. Washington, DC: IFPRI.

Pistorius, R. 1997. Scientists, Plants and Politics: A History of the Plant Genetic Resources Movement. Rome: International Plant Genetics Resources Institute. Plucknett, D. L. and N. J. H. Smith 1984. Networking in international agricultural research. Science 225: 989-993.

Raitzer, D. A. and T. G. Kelley 2008. Benefit-cost meta-analysis of investment in the International Agricultural Research Centers of the CGIAR. Agricultural Systems 96: 108-123.

Raitzer, D. and G. W. Norton 2009. Prioritizing Agricultural Research for Development: Experiences and Lessons. Wallingford: CABI.

Reij, C. and A. Waters-Bayer (eds) 2001. Farmer Innovation in Africa: A Source of Inspiration for Agricultural Development. London: Earthscan.

Reijntes, C., B. Haverkort and A. Waters-Bayer 1992. Farming for the Future. An Introduction to Low-External-Input and Sustainable Agriculture. Leusden, NL: ILEIA. Richards, P. 1985. Indigenous Agricultural Revolution: Ecology and Food Production in West Africa London: Hutchinson \& Company.

Roe, E. M. 1991. Development narratives, or making the best of blueprint development. World Development 19: 287-300.

Ruttan, V. 1982. Agricultural Research Policy. Minneapolis: University of Minnesota Press.

Sandbrook, R. 1985. The Politics of Africa's Economic Stagnation. Cambridge: Cambridge University Press.

Satyanarayana, A., T. M. Thiyagarajan and N. Uphoff 2007. Opportunities for water saving with higher yield from the system of rice intensification. Irrigation Science 25: 99-115. 
Scoones, I. 2009. The politics of global assessments: the case of the International Assessment of Agricultural Knowledge, Science and Technology for Development (IAASTD). Journal of Peasant Studies 36: 547-571.

Scoones, I. and J. Thompson (eds) 1994. Beyond Farmer First: rural people's knowledge, agricultural research and extension practice. London: Intermediate Technology Publications Ltd.

Scoones, I. and J. Thompson 2009 (eds). Farmer First Revisited: Innovation for Agricultural Research and Development. London: Practical Action Publishing. Senthilkumar, K., P. S. Bindraban, T. M. Thiyagarajan, N. de Ridder and K. E. Giller 2008. Modified rice cultivation in Tamil Nadu, India: Yield gains and farmers' (lack of) acceptance. Agricultural Systems 98: 82-94.

Sheehy, J. E., S. Peng, A. Dobermann, P. L. Mitchell, A. Ferrer, J. C. Yang, Y. B. Zou, X. H. Zhong and J. L. Huang 2004. Fantastic yields in the system of rice intensification: fact or fallacy? Field Crops Research 88: 1-8.

Shrum, Wesley and Patricia Campion 2000. Are Scientists in Developing Countries Isolated? Science Technology and Society 5: 1-34.

Silici, L., P. Ndabe, T. Friedrich and A. Kassam 2011. Harnessing sustainability, resilience and productivity through conservation agriculture: the case of likoti in Lesotho. International Journal of Agricultural Sustainability 9: 137-144.

Sinha, S. K. and J. Talati 2007. Productivity impacts of the system of rice intensification (SRI): A case study in West Bengal, India. Agricultural Water Management 87: 55-60.

Smith, Michael B. 2001. "Silence, Miss Carson!" Science, Gender, and the Reception of "Silent Spring". Feminist Studies 27: 733-752.

Sperling, L., J. A. Ashby, M. E. Smith, E. Weltzien and S. McGuire 2001. A framework for analyzing participatory plant breeding approaches and results. Euphytica 122: 439-450. 
Sperling, L. and P. Berkowitz 1994. Partners in Selection: Bean Breeders and Women Bean Experts in Rwanda. Washington DC: CGIAR.

Spielman, D. J., F. Hartwich and K. Grebmer 2010. Public-private partnerships and developing-country agriculture: evidence from the international agricultural research system. Public Administration and Development 30: 261-276.

Spielman, D.J. and R. Pandya-Lorch (eds) 2009. Millions Fed: Proven Successes in Agricultural Development. Washington, DC: IFPRI.

Stoop, W. A., A. Adam and A. Kassam 2009. Comparing rice production systems: A challenge for agronomic research and for the dissemination of knowledge-intensive farming practices. Agricultural Water Management 96: 1491-1501.

Stoop, W. A. and A. H. Kassam 2005. The SRI controversy: a response. Field Crops Research 91: 357-360.

Stoop, W. A., N. Uphoff and A. Kassam 2002. A review of agricultural research issues raised by the system of rice intensification (SRI) from Madagascar: opportunities for improving farming systems for resource-poor farmers. Agricultural Systems 71: 249-274.

Streeten, P. 1987. Structural adjustment: A survey of the issues and options. World Development 15: 1469-1482.

Sumberg, J. 2002. The logic of fodder legumes in Africa. Food Policy 27: 285-300.

Sumberg, J. 1998. Mixed farming in Africa: the search for order, the search for sustainability. Land Use Policy 15: 293-317.

Sumberg, J. 2005. Systems of innovation theory and the changing architecture of agricultural research in Africa. Food Policy 30: 21-41.

Sumberg, J., R. Irving, E. Adams and J. Thompson 2012a. Success making and success stories: agronomic research in the spotlight. In Contested Agronomy: Agricultural Research in a Changing World, eds. James Sumberg and John Thompson. London: Routledge. 
Sumberg, J., C. Okali and D. Reece 2003. Agricultural research in the face of diversity, local knowledge and the participation imperative: theoretical considerations. Agricultural Systems 76: 739-753.

Sumberg, J., J. Thompson and P. Woodhouse 2012b. Contested agronomy: agricultural research in a changing world. In Contested Agronomy: Agricultural Research in a Changing World, eds. James Sumberg and John Thompson. London: Routledge.

Tansey, G. and T. Rajotte (eds) 2008. The Future Control of Food: A Guide to International Negotiations and Rules on Intellectual Property, Biodiversity and Food Security. London: Earthscan

Tatum, L. A. 1971. The Southern Corn Leaf Blight epidemic. Science 171: 11131116.

Teubal, M. 2009. Agrarian Reform and Social Movements in the Age of Globalization Latin America at the Dawn of the Twenty-first Century. Latin American Perspectives 36: $9-20$.

The World Bank 2007. Agriculture for Development: World Development Report 2008. Washington DC: The World Bank.

Thompson, J. and I. Scoones 1994. Challenging the populist perspective: Rural people's knowledge, agricultural research and extension practice. Agriculture and Human Values 11: 58-76.

Tripp, R. 2005. Self-Sufficient Agriculture: Labour and Knowledge on Small-Scale Farming. London: Earthscan.

Uphoff, N., A. Kassam and W. Stoop 2008. A critical assessment of a desk study comparing crop production systems: The example of the 'system of rice intensification' versus 'best management practice'. Field Crops Research 108: 109114. 
Van Bueren, E. T. L., P. C. Struik and E. Jacobsen 2002. Ecological concepts in organic farming and their consequences for an organic crop ideotype. Netherlands Journal of Agricultural Science 50: 1-26.

Van Huis, A. and F. Meerman 1997. Can we make IPM work for resource-poor farmers in sub-Saharan Africa? International Journal of Pest Management 43: 313320.

Vanloqueren, G. and P. V. Baret 2009. How agricultural research systems shape a technological regime that develops genetic engineering but locks out agroecological innovations. Research Policy 38: 971-983.

von Kaufmann, R. 2007. Integrated agricultural research for development: Contributing to the comprehensive Africa agricultural development programme (IAR4D in CAADP). In Advances in Integrated Soil Fertility Management in subSaharan Africa: Challenges and opportunities, eds. A. Bationo, B. Waswa, J. Kihara and J. Kimetu. Dordrecht: Springer.

Weyland, K. 1996. Neopopulism and neoliberalism in Latin America: Unexpected affinities. Studies in Comparative International Development 31: 3-31.

Wield, D. V., J. Chataway and M. Bolo 2010. Issues in the political economy of agricultural biotechnology. Journal of Agrarian Change 10 342-366.

Williamson, J. 1993. Democracy and the Washington Consensus. World Development 21: 1329-1336.

Wolmer, W. and I. Scoones 2000. The science of 'civilized' agriculture: the mixed farming discourse in Zimbabwe. African Affairs 99: 575-600.

Woodhouse, P. 2010. Beyond Industrial Agriculture? Some Questions about Farm Size, Productivity and Sustainability. Journal of Agrarian Change 10: 437-453. Woodhouse, P. 2012. Water in African agronomy. In Contested Agronomy: Agricultural Research in a Changing World, eds. James Sumberg and John Thompson. London: Routledge. 
